\title{
PELATIHAN PEMBUATAN SABUN PADAT SPIRULINA UNTUK SISWA SMA/SMK DI SURABAYA DAN SIDOARJO
}

\author{
Diah Karunia Binawati ${ }^{1)}$, Sukarjati ${ }^{2)}$, Susie Amilah ${ }^{3)}$ \\ 1,2,3 Fakultas Sains Dan Teknologi, Universitas PGRI Adi Buana Surabaya \\ Email: diahkb@unipasby.ac.id ${ }^{1)}$ sukarjati@unipasby.ac.id ${ }^{2)}$
}

\begin{abstract}
Abstrak
Spirulina adalah sianobakterium multiseluler, walaupun mirip dengan bakteri tetapi Spirulina mempunyai mekanisme fotosintesis yang mirip dengan yang ditemukan pada tanaman. Spirulina merupakan mikroalga sel tunggal yang hidup di air dan berkembang biak dengan cara membelah diri ini dikenal sebagai sumber nutrisi nabati terlengkap yang kaya akan asam amino esensial, vitamin, mineral dan karotenoid (Sitorus, 2015). Kandungan nutrisi Spirulina yang lengkap mengakibatkan Spirulina semakin banyak digunakan untuk kebutuhan manusia baik dalam bidang pangan maupun kecantikan. Pelatihan pembuatan sabun padat transparan Spirulina bertujuan untuk memberikan pengetahuan dan ketrampilan kepada siswa SMA/SMK di Surabaya dan Sidoarjo tentang pengaplikasian ilmu dan teknologi dalam menghasilkan sabun padat transparan untuk membersihkan dan menyehatkan kulit wajah. Bahan yang digunakan adalah Chip soap $450 \mathrm{~g}$, Lexaine C 0,06 g, Carbowax liquid 0,03 g, Propilen glikol 0,03 g, Fixolite $12 \mathrm{~g}$, Spirulina $9 \mathrm{~g}$, Alkohol $96 \% 30 \mathrm{ml}$, parfum. Hasil pelatihan ini memberikan informasi tentang penggunaan Spirulina untuk pembuatan sabun padat transparan dan mempraktekkan secara langsung pembuatan sabun padat transparan, sehingga diharapkan dapat menumbuhkan jiwa entrepreneur siswa.
\end{abstract}

Kata kunci: sabun padat transparan, kulit wajah, Spirulina

\begin{abstract}
Spirulina is a multicellular cyanobacterium, although similar to bacteria, but Spirulina has a photosynthesis mechanism that is similar to those of plants. Spirulina is a single cell microalga that lives in the water and reproduce by dividing itself. Spirulina is known as the most complete source of vegetable nutrition because it's rich of essential amino acid, vitamin, mineral, and carotenoids (Sitorus, 2015). The complete nutrition in Spirulina makes it more widely known and used to fulfill the human needs, both in the fields of food and beauty. The training of making Spirulina transparent solid soap aims to provide knowledge and skills to students of high school and vocational school in Surabaya and Sidoarjo regarding the application of science and technology in producing transparent solid soap to cleanse and nourish the facial skin. The ingredients used are Chip soap $450 \mathrm{~g}$, Lexaine C 0,06 g, Carbowax liquid 0,03 g, Propilen glikol 0,03 g, Fixolite $12 \mathrm{~g}$, Spirulina $9 \mathrm{~g}$, Alcohol $96 \% 30$ $\mathrm{ml}$, and Perfume. The purpose of this study is to give information and direct practice about the use of Spirulina to make transparent solid soap, so this training is expected to grow the entrepreneurial sense of the students.
\end{abstract}

Keywords: transparent solid soap, facial skin, Spirulina

\section{PENDAHULUAN}

Kulit adalah bagian terpenting dari tubuh kita yang berfungsi untuk melindungi bagian dalam tubuh dari gangguan fisik maupun mekanik, gangguan panas atau dingin, gangguan sinar radiasi atau sinar ultraviolet, 
gangguan kuman, bakteri, jamur, atau virus. Kulit juga berfungsi sebagai tempat keluarnya keringat atau sisa metabolisme dalam tubuh, sebagai indera peraba, serta berfungsi untuk pengatur suhu tubuh. Sabun merupakan sediaan kosmetik yang dapat digunakan membersihkan kotoran dan sebagai perlindungan nonalamiah (Sukawati dkk, 2016).

Menurut Standar Nasional Indonesia (SNI) tahun 1994 sabun mandi didefinisikan sebagai senyawa Natrium dengan asam lemak yang digunakan sebagai pembersih tubuh, berbentuk padat, berbusa, dengan atau penambahan lain serta tidak menyebabkan iritasi pada kulit. Syarat mutu sabun mandi padat yang ditetapkan oleh SNI yaitu sabun padat memiliki kadar air maksimal $15 \%$, jumlah alkali bebas maksimal $0,1 \%$ dan jumlah asam lemak bebas kurang dari 2,5\%.

Sabun yang berkualitas baik juga dipengaruhi oleh bahan baku yang digunakan. Sabun mandi biasanya dibuat dengan campuran lemak atau minyak. Produksi sabun saat ini sangat melimpah namun sebagian besar dalam pembuatannya masih menggunakan bahan sintetik yang sangat membahayakan bagi kulit manusia. Contoh bahan aktif sintetik yang banyak disorot saat ini adalah diethanolamine (DEA), Sodium Lauryl Sulfate (SLS) dan triclosan yang terdapat hampir di semua sabun mandi yang beredar di pasaran. Kegunaan sabun dapat ditingkatkan yang tadinya hanya menjadi bahan pembersih, kemudian dapat menjadi sediaan obat jika ditambahkan bahan aktif tertentu.

Sabun padat transparan merupakan salah satu inovasi sabun yang menjadikan sabun lebih menarik. Sabun transparan mempunyai busa yang lebih halus dibandingkan dengan sabun yang tidak transparan (Qisty, 2009 dalam Widyasanti dkk, 2016). Faktor yang dapat mempengaruhi transparansi sabun adalah kandungan alkohol, gula, dan gliserin dalam sabun. Ketika sabun akan dibuat jernih dan bening, maka hal yang paling penting adalah kualitas gula, alkohol, dan gliserin. Kandungan gliserin baik untuk kulit karena berfungsi sebagai pelembab pada kulit dan membentuk fasa gel pada sabun (Rahadiana dkk, 2014).

Penambahan bahan lain sebagai campuran dalam pembuatan sabun padat transparan juga dapat memaksimalkan manfaat dari sabun padat yang digunakan. Bahan campuran yang digunakan dalam proses pembutan sabun pada penelitian ini adalah spirulina. Spirulina platensis telah dieksploitasi secara komersial untuk produksi suplemen pangan, pakan dan obat-obatan karena dapat menghasilkan sejumlah besar produk berharga, seperti fikosianin dan asam lemak tak jenuh rangkap (Alonso dan Maroto, 2000; Deshnium et al., 2000). Spirulina platensis adalah sianobakterium multiseluler, terdiri dari filamen biru-hijau berbentuk helik atau spiral dengan ukuran diameter sekitar 1$12 \mu \mathrm{m}$ dalam trikoma yang tidak bercabang, motil, dan tidak memiliki heterokista yang bertindak sebagai pengikat nitrogen. Walaupun mirip dengan bakteri, Spirulina mempunyai mekanisme fotosintesis yang mirip dengan yang ditemukan pada tanaman. Beberapa mikroalga ini juga ditemukan dapat tumbuh secara heterotrofik dalam gelap dan memanfaatkan berbagai senyawa organik. Namun karena mekanisme pengambilan nutrisi lebih dominan dilakukan melalui fotoautotrofik, organisme ini diklasifikasikan ke dalam kerajaan plantae atau tanaman.

Spirulina merupakan mikroalga sel tunggal yang hidup di air dan berkembang biak dengan cara membelah diri ini dikenal sebagai sumber nutrisi nabati terlengkap yang kaya akan asam amino esensial, vitamin, mineral dan karotenoid (Sitorus, 2015). Kandungan nutrisi Spirulina yang lengkap mengakibatkan Spirulina semakin banyak digunakan untuk kebutuhan manusia baik dalam bidang pangan maupun kecantikan.

Pelatihan pembuatan sabun transparan pada program pengabdian pada masyarakat yang dilaksanakan oleh program studi Biologi bertujuan untuk memberikan pengetahuan dan 
keterampilan kepada siswa SMA/SMK tentang pengaplikasian ilmu dan teknologi dalam menghasilkan sabun transparan yang berasal dari bahan spirulina. Dengan adanya kegiatan ini diharapkan dapat menumbuhkan minat dan kreativitas siswa SMA/SMK pada bidang teknologi dan pengaplikasiannya dalam kehidupan sehari-hari.

$$
\text { Adapun manfaat dilaksanakan }
$$

pengabdian pada masyarakat bagi siswa SMA/SMK adalah menambah pengetahuan tentang berbagai peran Spirulina yang ada di industri pangan, obat-obatan dan kosmetik.

\section{METODE PELAKSANAAN}

Peserta program pengabdian kepada masyarakat Prodi Biologi FMIPA UNIPA berasal dari Siswa dan Siswi SMA/SMK di Surabaya dan Sidoarjo.

a. Pelaksanaan pelatihan:

Dilakukan di laboratorium Biologi Dasar program studi Biologi Universitas PGRI Adi Buana Surabaya pada tanggal 1-30 September 2020. Peserta pelatihan diberi materi Cara pembuatan Sabun Padat berbahan dasar Spirulina, dan dilakukan praktek pembuatan sabun Spirulina.

b. Alat dan Bahan yang digunakan:

Alat yang digunakan:

Pemanas, beakerglass, pengaduk, cetakan, plastik dan label.

Bahan yang digunakan:

Spirulina, Chip soap $450 \mathrm{~g}$, Lexaine C 0,06 g, Carbowax liquid 0,03 g, Propilen glikol 0,03 g, Fixolite $12 \mathrm{~g}$, Spirulina $9 \mathrm{~g}$, Alkohol $96 \% 30$ ml, Perfum.

c. Proses pembuatan sabun padat transparan meliputi beberapa tahapan yaitu:

a) pemanasan bahan padatan,

b) pencampuran/blending semua bahanbahan pembuatan sabun padat yang sudah dicairkan dengan bahan cair,

c) pengadukan yang dilakukan secara kontinyu agar sabun padat transparan bertekstur bagus dan tidak menggumpal,

d) pencetakan sabun padat pada wadah yang disesuaikan dengan kebutuhan, e) pengemasan sabun padat dengan kemasan yang menarik.

\section{HASIL DAN PEMBAHASAN}

Program Pengabdian pada Masyarakat (PPM) yang dilaksanakan di Program Studi Biologi FMIPA Universitas PGRI Adi Buana Surabaya ini dihadiri oleh 42 siswa/siswi yang berasal dari SMA/SMK Surabaya dan Sidoarjo.

Kegiatan pelatihan dibuka dengan sambutan pembukaan dari Bapak Wakil Dekan I FMIPA dan Ibu Ketua Program Studi Biologi. Kegiatan pertama diawali dengan penyampaian pretest (tes awal) kepada siswasiswi SMA/SMK untuk mengetahui pengetahuan awal mengenai budidaya spirulina dan pembuatan sabun spirulina. Kegiatan kedua, berupa pemberian materi yang disampaikan dalam bentuk metode presentasi untuk menjelaskan cara-cara pembuatan sabun transparan dan diselingi diskusi. Kegiatan ketiga, berupa praktek langsung pembuatan sabun padat transparan berbahan dasar Spirulina. Siswa/siswi SMA/SMK sangat antusias mengikuti kegiatan praktek pembuatan sabun spirulina.

Pada akhir kegiatan peserta pelatihan juga diberi lembaran post test (tes akhir) untuk mengetahui manfaat dari pelatihan pembuatan sabun berbahan dasar spirulina, peserta juga menyampaikan beberapa pesan, saran dan kesan, sehingga data tersebut bisa menjadi bahan evaluasi pelaksanaan kegiatan pelatihan. Saran yang diberikan diantaranya peserta memberikan apresiasi terhadap materi yang disampaikan dan peserta menginginkan kegiatan lanjutan yaitu ingin belajar tentang cara memasarkan produk sabun Spirulina.

Kegiatan PPM ini diharapkan dapat meningkatkan motivasi usaha, kesadaran, pengetahuan dan keterampilan siswa/siswi melalui penerapan teknologi tepat guna untuk mengolah spirulina menjadi produk sabun handmade yang mempunyai nilai jual tinggi. 


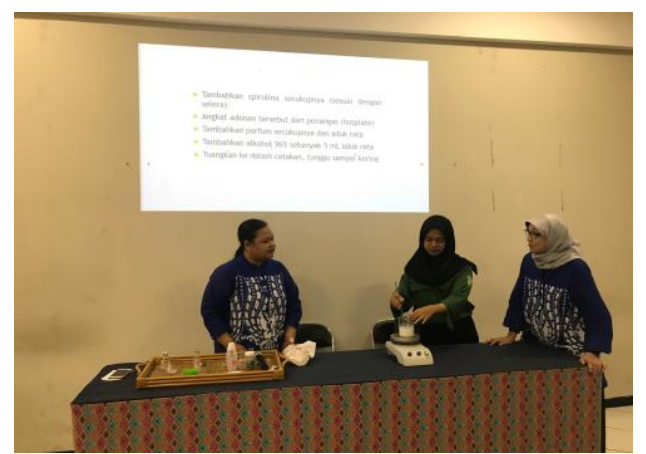

Gambar 1. Tim Dosen memperagakan cara membuat sabun transparan

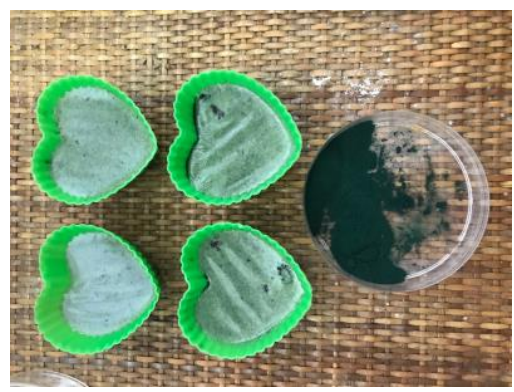

Gambar 2. Produk sabun padat transparan Spirulina

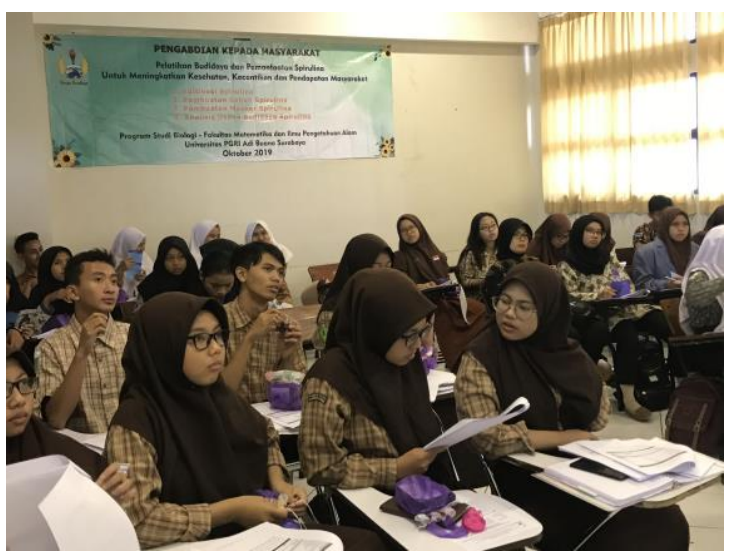

Gambar 3. Siswa SMA/SMK peserta pelatihan

\section{KESIMPULAN}

Kesimpulan dari kegiatan pelatihan pembuatan sabun transparan ini adalah kegiatan berjalan dengan baik dan lancar dan penjelasan materi dan praktek oleh tim Dosen Biologi FMIPA juga dapat dipahami dengan baik oleh seluruh peserta pelatihan. Perlu pendampingan manajemen, teknologi tepat guna, dan pemasaran yang memungkinkan dapat meningkatkan nilai tambah produk sabun transparan berbahan dasar spirulina.

\section{UCAPAN TERIMAKASIH}

Terimakasih disampaikan kepada Pimpinan Universitas PGRI Adi Buana Surabaya yang telah memfasilitasi prodi Biologi untuk melaksanakan kegiatan pengabdian kepada masyarakat, serta kepada Kepala Sekolah SMA/SMK di Surabaya dan Sidoajo yang telah berkenan mendampingi siswanya untuk mengikuti kegiatan pelatihan ini.

\section{REFERENSI}

Ningsih E. K. Udyani, A. Budianto, S. Julaika, D. Y. Purwaningsih, dan D. R. Zuchrilah. 2017. Pelatihan Pembuatan Sabun Transparan pada SMA 17 untuk Meningkatkan Keterampilan. JPP IPTEK, Vol (1) No. 1: 55-58.

Qisti, Rachmiati. 2009. Sifat Kimia Sabun Transparan dengan Penambahan Madu pada Konsentrasi yang Berbeda. Bogor, Program Studi Teknologi Hasil Ternak Fakultas Peternakan Institut Pertanian Bogor.

Rahadiana, P., Andayani L.S. 2014. Pabrik Sabun Transparan Beraroma Terapi dari Minyak Jarak dengan Proses Saponifikasi Trigliserida Secara Kontinyu. Program Studi D3 Teknik Kimia FTI-ITS.

Sukawati, Y,. H. Warnida dan A. V. Artha. 2016. Formulasi Sediaan Sabun Mandi Padat Ekstrak Etanol Umbi Bawang Tiwai (Eleutherine bulbosa (Mill.) Urb.). Media Farmasi Vol. 13(1): 14-22.

Yuniarti, R., Y. Sumantri, W. Azlia, dan I. Hamdala. 2016. IbM Pelatihan Pembuatan Sabun yang Ramah Lingkungan pada Panti Asuhan Al Husna untuk Meningkatkan Keterampilan. Laporan Pengabdian 
kepada Masyarakat, Teknik Industri, Universitas Brawijaya.

Widyasanti, A, C.L. Farddani dan D. Rohdiana. 2016. Pembuatan Sabun Padat Transparan Menggunakan Minyak Kelapa Sawit (Palm oil) Dengan Penambahan Bahan Aktif Ekstrak Teh Putih (Camellia sinensis). Jurnal Teknik Pertanian Lampung. Vol. 5(3): 125-136.

Widyasanti, A., Putri, S.H, dan Dwiratna S.N.P. 2016. Upaya Pemberdayaan Masyarakat melalui Pelatihan Pembuatan Produk Sabun Berbasis komoditas local di Kecamatan Ciamis. Dharmakarya : Jurnal Aplikasi Ipteks untuk Masyarakat. Vol.5 (1) : 29-33 